\title{
ACRL continuing education courses at ALA Annual Conference in Chicago
}

The Association of College and Research Libraries (ACRL) will be sponsoring nine continuing education courses at the ALA Annual Conference in Chicago this summer. The courses will range in length from one to two days and will deal with the following areas: 1) management skills; 2) library skills; and 3) professional development. All courses will be given at the Hyatt Regency Hotel in Chicago.

A Certificate of Completion will be awarded participants in each course. Successful completion of 10 contact hours of continuing education is equal to one Continuing Education Unit (CEU). ACRL maintains a CEU record for each participant.

Advance registration by June 7 is required and registration is limited. A late registration fee of $\$ 15$ will be charged.

To register, send in a completed registration form to Sandy Whiteley, ACRL/ALA, $50 \mathrm{E}$. Huron St., Chicago, IL 60611-2795. Details of the courses follow:

\section{LibraRians AS SUPERVISORS}

CE 101 provides participants with skills necessary to become effective supervisors in library organizations. Helps participants develop awareness and understanding of current managerial concepts and practices. Specific objectives include: to increase self-awareness of behavior and managerial philosophy; to develop a greater appreciation of the supervisor's role and contribution to improving library performance; to gain an understanding of the skills required for effective supervision; and to examine individual approaches to supervision in response to the needs and demands of particular situations.

Instructor: Maureen Sullivan, Head of Personnel, Yale University Library.

Date: Friday, July 5, 9:00 a.m.-5:00 p.m.

Fee: ACRL members $\$ 95$; non-members $\$ 135$.

\section{Managing Student Workers in ACAdemic Libraries}

CE 107 will help participants develop strategies for better management of student workers. In addition to providing an opportunity for participant interaction, the course seeks to clarify the nature of the student workers's role in academic libraries and the role of the supervisor of student workers; to identify management theories appropriate to student workers; to recognize the importance of selection, training, and supervision of student workers; to identify dilemmas or problems which occur in the management of student workers; and to become familiar with various ways in which policies and procedures can be communicated to student workers. The course is intended for librarians who have had at least one year of experience managing student workers or who have had at least one year of experience managing supervisors of student workers.

Instructors: Michael D. Kathman, director of libraries \& media services, St. John's University; and Jane Kathman, assistant professor of economics \& business administration, College of St. Benedict.

Date: Friday, July 5, 8:30 a.m. $-5: 00$ p.m.

Fee: ACRL members $\$ 95$; non-members $\$ 135$.

\section{Job Training: Developing Training Plans for Your StafF}

CE 110a explains why initial orientation and training is critical to effective operation of library departments. The course covers: areas requiring training for the new employee, for performance improvement, in operational problems or changes and for development of the employee: and the responsibility of the supervisor in planning, conducting, and evaluating training. The course reviews learning principles. Participants will work on developing a training plan and/or materials for their own employees.

Instructor: Anne Lipow, director of library education, University of California, Berkeley.

Date: Friday, July 5, 9:00 a.m.-5:00 p.m.

Fee: ACRL members $\$ 95$; nonmembers $\$ 135$.

\section{Principles of Strategic Planning in THE LIBRARY ENVIRONMENT}

CE 111 pro:rides a theoretical background and practical experience in applying strategic planning processes to library planning. The specific objectives of the course are: to provide background information on strategic planning as a process; to identify problems encountered with past longrange planning efforts; to describe several strategic planning models including the "desired futures" model; to provide participants with an opportunity to practice the use of the desired futures model cooperatively and applied to their own environment; and to receive feedback on that experience. The material covered in this course is applicable to strategic planning for all types of libraries.

Instructor: Julie A.C. Virgo, vice-president, The Carroll Group.

Date: Thursday, July 4, 9:00 a.m.-5:00 p.m.

Fee: ACRL members $\$ 95$; non-members $\$ 135$.

An Introduction to Maps

in Libraries: MaPS as Information ToOls

CE 201 explores for the nonspecialist the information potential of maps in the academic library environment, as well as acquisitions, collection de- 


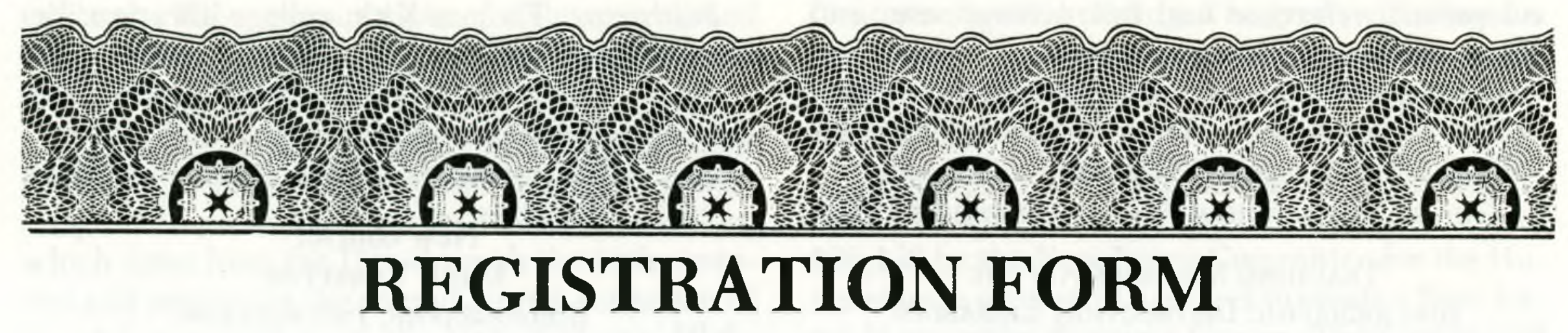

\section{CONTINUING EDUCATION COURSES}

PLEASE PRINT

NAME

AFFILIATION

STREET

(indicate home or work)

CITY

STATE ZIP

DAYTIME PHONE

ALA/ACRL MEMBERSHIP \#

PLEASE CIRCLE THE APPROPRIATE DOLLAR AMOUNT FOR THE COURSE OF YOUR CHOICE, AND INDICATE YOUR PREFERENCES IN THE MARGIN (1st, 2nd, and 3rd).

Course

ACRL Member Non-member

CE 101 Librarians as Supervisors

$\$ 95 \quad \$ 135$

CE 107 Managing Student Workers

$\$ 95 \quad \$ 135$

CE 110a Job Training

$\$ 95$

$\$ 135$

CE 111 Strategic Planning

$\$ 95$

$\$ 135$

CE 201 Maps in Libraries

$\$ 95$

$\$ 135$

CE 202 Teaching Methods for the BI Librarian

$\$ 190$

$\$ 270$

CE 205 How to Teach Science Reference Materials

$\$ 140$

$\$ 200$

CE 206 Using Video for Bibliographic Instruction

$\$ 95$

$\$ 135$

CE 501 Writing the Journal Article and Getting It Published

$\$ 95$

$\$ 135$

${ }^{*}$ Late registration fee

$\$ 15$

$\$ 15$

\section{ENTER TOTAL AMOUNT ENCLOSED}

${ }^{*}$ Fee for registration after June 7 .

CONFIRMATION: Written confirmations will be made.

CANCELLATIONS: Written notice of cancellations received by June 7 will be honored subject to a

$\$ 15$ cancellation charge. No refunds for cancellations after June 7 .

You may make checks payable to ACRL and return them with this form to:

ACRL-Continuing Education

American Library Association

50 E. Huron St.

Chicago, IL 60611

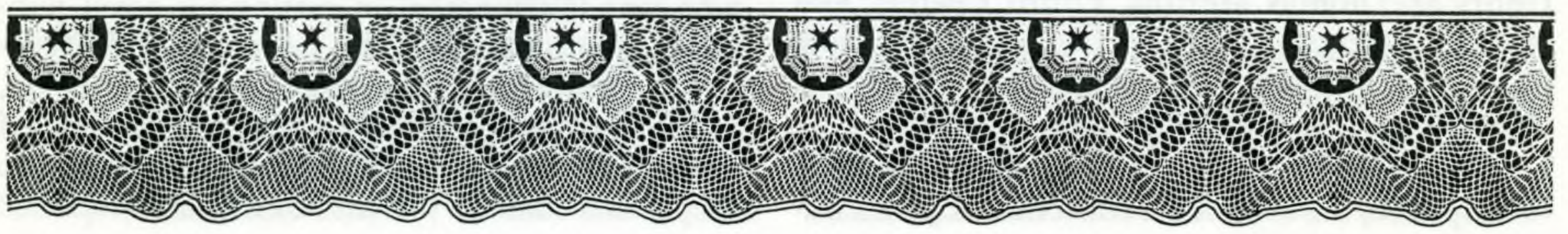


celopment, reference and instructional use, and space and equipment requirements.

Instructor: David A. Cobb, assistant director for special collections, University of Illinois Libraries.

Date: Friday, July 5, 9:00 a.m.-5:00 p.m.

Fee: ACRL members $\$ 95$; non-members $\$ 135$.

Teaching Methods For the

BIBLIOGRAPHIC INSTRUCTION LiBRARIAN

CE 202 provides an introduction to basic learning theory and alternate instructional methods used in library instruction. Participants will work on designing and modeling an instructional session.

Instructor: Cerise Oberman, head, Walter Reference Library, University of Minnesota.

Date: Thursday, July 4 and Friday, July 5, 9:00 a.m. $-5: 00$ p.m.

Fee: ACRL members $\$ 190$; non-members $\$ 270$.

How to Teach Science Reference

MATERIALS: A WORKSHOP FOR LiBRARIANS WhO SERVE THE UNDERGRADUATE

CE 205 examines the search strategies and reference tools (especially such science periodical indexes as the H.W. Wilson indexes, Biological Abstracts, Chemical Abstracts, and Science Citation Index) that are particularly useful to undergraduate science majors. Equal emphasis is given to methods of teaching these search strategies and the use of these reference tools. Methods of learning how to use new science reference materials are also covered.
Instructor: Thomas Kirk, college librarian, Berea College.

Date: Thursday, July 4, 1:30-5:00 p.m.; Friday, July 5, 9:00 a.m.-5:00 p.m.

Fee: ACRL members $\$ 140$; non-members $\$ 200$.

\section{New course! \\ USING VIDEO FOR \\ BIBLIOGRAPHIC INSTRUCTION}

CE 206 course description will be available after April 1 from the ACRL Office.

Instructor: Thomas McNally, head, Circulation Department, Ohio State University.

Date: Friday, July 5, 9:00 a.m.-5:00 p.m.

Fee: ACRL members $\$ 95$; non-members $\$ 135$.

\section{Writing the Journal Article and Getting It Published}

CE 501 provides participants with an overview of the publishing process and helps them devise an effective strategy for publishing their work. Topics will include selection of a publishing medium, preparation of the manuscript, submission of the manuscript, and pre- and post-publication matters.

Instructor: Richard D. Johnson, director of libraries, State University College, Oneonta, New York (formerly editor of College \& Research Libraries, co-editor of New Horizons for Academic Librarians and acting editor of Choice).

Date: Thursday, July 4, 9:00 a.m.-5:00 p.m.

Fee: ACRL members $\$ 95$; non-members $\$ 135$.

\section{$\star \star \star \star$}

\section{Acquisitions}

- Brown University's John Hay Library, Providence, Rhode Island, has acquired an additional 80 linear feet of the archives of the Unicorn Press of Greensboro, N.C. Together with the 67 linear feet and archival copies of publications previously acquired, this collection now comprises the production files of Alan Brilliant and the editorial files of Teo Savory for the period 1966-1984. The collection is notable for having correspondence and literary manuscripts, not only of such American authors as Thomas Merton, Philip Levine, and Daniel Berrigan, but also the foreign authors Ernesto Cardenal, Jacques Prévert, Guillevic, Horst Bienek, and Vo-Dinh, among others.

- Dartmouth College Library, Hanover, New Hampshire, has received a collection of Jack Lon- don books and materials from Marvin A. and Sue Rauch, of Far Rockaway, New York. The gift contains first editions of London's books, many first appearances of his books and short stories in magazines, critical and biographical books, and several signed letters and inscribed books. Especially noteworthy is a pencil portrait of London inscribed, "Yours for the Revolution, Jack London."

-Tulane University Library, New Orleans, has received the papers of John Kennedy Toole, author of A Confederacy of Dunces. The gift was presented by Toole's mother, Thelma Ducoing Toole, who was instrumental in getting his novel published posthumously. The papers include typescripts, printer's copy and page proofs of the novel, as well as thirteen foreign language editions. Of special interest are the letters that Toole wrote to his parents while he was in the army and stationed 